\title{
Education Level
}

National Cancer Institute

\section{Source}

National Cancer Institute. Education Level. NCI Thesaurus. Code C17953.

An indication of the years of schooling completed in graded public, private, or parochial schools, and in colleges, universities, or professional schools. 